DOI 10.18551/rjoas.2021-11.17

\title{
A PROBIT ANALYSIS OF FACTORS AFFECTING DECISIONS TO CONTINUE MAINTAINING SOIL CONSERVATION STRUCTURES AFTER ADOPTION OF THE TECHNOLOGY IN KERICHO COUNTY, KENYA
}

\author{
Kipsat Mary J.*, Bwari Mose Phoebe, Osewe D.O. \\ Department of Agricultural Economics and Rural Development, Maseno University, Kenya \\ *E-mail: mjkipsat@maseno.ac.ke
}

\begin{abstract}
Available literature shows that most famers abandon promoted soil conservation technologies soon after financial and technical supports cease. This is because technologies are launched without serious evaluation of factors affecting continued use of adopted technologies. This paper provides an analysis of the factors that influence the decision by farmers who have adopted soil conservation technologies to continue maintaining soil conservation structures once promotion support cease. Initial adoption of soil conservation is normally made easy by subsidies that aid in technology establishment. Extension agents are facilitated to educate farmers on the need to conserve soil. Soil conservation once established need to be maintained to serve the purpose of soil conservation. In the 1990s soil conservation subsidy was withdrawn with expectation that farmers would continue maintaining adopted soil conservation technologies. However, most farmers abandoned soil conservation structures as soon as conservation subsidy was withdrawn. A study was carried out in Kericho County to analyze factors believed to determine continued adoption of promoted soil conservation practices when subsidies are withdrawn. A random sample of 85 farmers was selected from Kericho County. Questionnaires were used to collect primary data from selected households. A lot of information on soil conservation efforts was sought from Lake Victoria Environmental Management Programme reports. The findings of the indicated that some of the analyzed variables significantly affected continued use of technologies. It is recommended that factors that were significant be considered in policy formulations related to sustainable use of soil conservation technologies. There is need to educate farmers to understand the role of soil conservation technologies in improved agricultural production so that farmers see the need to maintain the technologies.
\end{abstract}

\section{KEY WORDS}

Probit, factors, decisions, adoption, soil conservation.

Governments have over the years provided support for soil conservation in Kenya. The colonial government introduced conservation programs in Kenya in 1930s (Domínguez \& Luoma, 2020). Funds were committed to conserve soil and in 1938 a soil conservation service that mainly benefitted European farmers that lived near the railway line was formed. The extension service focused on construction of soil conservation structures. Funding was later advanced through ALDEV and then through the Swynnerton Plan in 1950s (Makana, 2021). Chiefs were used to oversee coercive soil conservation (Deflem, 1994; Tiffen et al., 1994) as a punishment for disobedience and evasion of paying poll tax (Awinsong, 2008). Coercive enforcement of soil conservation later led to widespread resistance as it was seen as part of colonialists' plan to distract Kenyans from struggling for freedom from colonial rule. Until 1973 conservation was not given attention by leaders/ politicians as it reminded them of colonial legacy (Nacoulma \& Guigma, 2015; SIDA, 1993).

The Government of Kenya (GoK) reintroduced soil conservation in 1974 to mitigate negative effects of soil erosion in Kenya's agricultural economy (Mati, 2016). In 1981, a PPCSCA was set up to conserve environment in general and soil in particular (Anyieni, 1986; Kilewe and Thomas, 1982). The PPCSCA created awareness on land degradation problems and need for conservation. In 1988, "catchment" approach to soil and water conservation was introduced with the aim of concentrating resources and efforts to specific areas 
(Mutisya, 2010). Identification and recommendations for addressing conservation problems were done with community participation as GoK provided technical advice and conservation tools to farmers. Studies have shown that soil conservation has unique attributes not possessed by other practices (Bellon and Taylor, 1993; Adesina and Zinnah, 1993; Adesina and Baidu-Forsen, 1995). Soil conservation must be established and maintained for a long time before yield improvements are noticed. Farmers rarely associate improved yields arising from soil conservation to conserving soil. When organizations promoting soil conservation withdraw financial and technical support; farmers are likely to abandon and sometimes actively destroy conservation structures.

The objective of the study was to analyze the factors postulated to affect decisions to abandon soil conservation. It was hypothesized that the factors did not significantly affect farmers' decisions to discontinue using soil conservation technologies after withdrawal of GoK support.

Four soil conservation technologies namely; terracing, unploughed strips, grass strips and, stone lines were selected for this study as the technologies have, for a long time, been promoted in the study area. Other technologies such as contour ploughing, diversion ditches, river bank dykes, plain ridging and gabion weirs promoted in the area were not analyzed because they were less common.

\section{METHODS OF RESEARCH}

This section presents study area, research design, sampling procedure, the sample frame, sample size, types and sources of data collected, data collection tools and data collection exercise as well data analysis tools.

Kericho County is an agricultural zone known for tea, coffee, maize, pyrethrum, and sugarcane production. Use of agrochemicals in production of cash crops has contributed to water pollution. The downstream effect of pollution in Lake Victoria includes emergence of water hyacinth, an indication of eutrophication. Kericho has many rivers and streams flowing westwards and is on the uplands of Nyando River basin with tributaries originating from Nandi and Tindiret hills in Nandi County and Londiani, Tindiret and West Mau forests in Kericho County (LVEMP, 1999). Climate in Kericho County is highland sub-tropical with high and well distributed rainfall with mean annual rainfall that ranged between $1000 \mathrm{~mm}$ and $1600 \mathrm{~mm}$. West Mau Forest, Kipkelion and Londiani received highest mean annual rainfalls of 1660, 1390 and $1250 \mathrm{~mm}$ respectively (LVEMP, 1999). Due to rugged terrain and high rainfall in the area, soil erosion was a major environmental degradation problem. Londiani, Kipkelion and Sigowet divisions of Kericho County provided study sites.

Both qualitative and quantitative research designs were used in this study.

The sample frame was that of selected farmers who lived in the selected divisions where soil conservation was promoted, due to being soil erosion prone. The sample frame also consisted of farmers who adopted soil conservation between 1992 and 2003 and were either continuing with the promoted soil conservation technologies or had abandoned the soil conservation practices.

Multistage sampling was used to select respondents. In this approach, at level one, purposive sampling was used to select 4 divisions where farmers' soil conservation was promoted, due to being soil erosion prone. At level two, simple random sampling was used to select 85 farmers from the 4 divisions.

The Questionnaire was used as a data collection tool. Ten enumerators were chosen from each division and trained on how to collect data using questionnaires. The questionnaires were pre-tested with a random sample of 40 farmers in Ainamoi Division, Kericho County. The enumerators conversant with farmers' local language and customs then undertook data collection by administering the questionnaire orally to respondents.

Primary data was collected from respondents interviewed during the study. Secondary data was collected from publications and reports from organizations like MoA, KARLO, KEFRI, LVEMP, ICRISAT, LBDA, FAO, DMD Limited, OSIENALA, RELMA, SIDA and ADRA. Variables believed to affect continued adoption or abandonment of technologies 
included income, decision maker's age, education level and sex, farm size, security of tenure, attitude towards protection of cultural sites and biophysical factors. Biophysical features considered extent of erosion problem and the unique features of the farm and were used as proxies. The variable biophysical features took a value of " 3 " if erosion problem was severe and if unique features of the farm existed, "2" if erosion problem was moderate and "1" if erosion was not a problem. Adesina et al. (2002) used severity of erosion problem as proxy for biophysical features. Their classification was "1" for high erosion, "2" for minor and "3" for no erosion problem.

To continue or abandon an already adopted technology is a choice decision. The theoretical framework within which human behavior is studied is theory of choice (Silberberg, 1978). The theory postulates that individual behavior is characterized by individual choice decisions and choice decisions are consequences of scarcity of goods and services. Farmer's choice decisions depend on postulates about individual preferences. The conceptualization of determinants of choice upon which neoclassical economics is based is conceived as interaction of two distinct phenomena: tastes and preferences, and opportunities or constraints (Silberberg, 1978). In this study, households were faced with choices between two alternatives: to continue or to abandon a technology. Qualitative response models are used to model adoption decisions.

Many researchers have used the probit model to analyze factors affecting industrial firm closures and decisions to abandon new industrial firms (Colombo and Demastro, 2001; Baden-Fuller, 1989; Lieberman, 1990; Suton, 1997; Jovanovich, 1982; Meta et al., 1995; Dunne et al., 1988). The Probit is a qualitative response model that assumes a cumulative normal probability function in which explanatory variable $\left(Z^{*}\right)$ is a normally distributed random variable. The probability that $Z^{*} \leq Z_{i}$ is computed from cumulative normal probability function (Ghosh, 1991; Cramer, 1991; Pindyck and Rubinfeld, 1991). The Probit model however has the problem that it assumes that $Z$ is a normally distributed random variable. This may not be justified theoretically (Pindyck and Rubinfeld, 1991). Endogeneity (heteroscedasticity) in the Probit models was tested using the Spearman's rank correlation test. To reduce the problem of heteroscedasticity variables included in the probit model were first subjected to stepwise elimination procedure.

In this study the dependent variable in the Probit model was binary; to continue with soil conservation taking value of 1 , if soil conservation technology that was adopted during period 1993-2002 had not been abandoned by the year 2003 and a value of 0 , if respondent decided to abandon an adopted technology during the period 1993-2003. Decision to continue with soil conservation in this study was based on comparison of explanatory variables $\left(\mathrm{W}_{\mathrm{i}}\right)$ of continuing with adoption or abandoning the technology. The probability [continue with soil conservation $=1]=f\left(W_{1}, W_{2}, W_{3}, W_{4}, . ., W_{n}\right)$, where $W_{1}, W_{2}, W_{3}, W_{4} \ldots ., W_{n}$ were the independent variables postulated to affect decisions (Adesina and Zinnah, 1993; Rahm and Huffman, 1994). Decision to continue with technique can be defined by symbol "c" and to abandon "a". Net benefits of the $i^{\text {th }}$ farmer for continued adoption $\mathrm{Yi}^{*}$ is given by the difference between positive benefits farmers perceive to get from the technology and those of abandoning it. $\mathrm{Yi}^{*}>0$ corresponds to attributes in favor of continuing with soil conservation exceeding that of abandoning, while $\mathrm{Yi}^{*} \leq 0$ refers to attributes in favor of continuing with soil conservation being less than in favor of abandoning the technology. This was modeled as:

$$
\mathrm{Yi}^{\star}=\sum_{j=1}^{c} \beta j \mathrm{~W}_{\mathrm{ij}}+\mathrm{u}
$$

Where $\mathrm{i}=1,2, . .5, \mathrm{~W}_{\mathrm{ij}}$ are the exogenous variables and $\mathrm{u}$ is the error term. The observed variables are $Y_{i}=1$ when $Y_{i}^{*}>0$ and $Y_{i}^{*} \leq 0$ for the $i^{\text {th }}$ farmer. $Y_{i}$ are the binary choices in which $\mathrm{Yi}=1$ when decision to continue with technology prevail over decision to abandon the technology. $Y_{i}=0$ when the decision- maker chooses to abandon soil conservation. $\sum_{j=1}^{c} \beta j \mathrm{~W}_{\mathrm{ij}}$ is an index function of the effect of explanatory variables on choice behavior. The $\mathrm{i}^{\text {th }}$ farmer will choose to continue with conservation if $\mathrm{u}>-\sum_{j=1}^{c} \beta j \mathrm{~W}_{\mathrm{ij}}$. The model is specified as Probit model (Negatu and Parikh, 1999), where $P_{i}$ is probability of continuing to maintain 
with soil conservation. $\mathrm{P}_{\mathrm{i}}=$ probability $(\mathrm{Yi}=1)=$ probability $\left(\sum_{j=1}^{c} \beta j \mathrm{~W}_{\mathrm{ij}}+\mathrm{u}_{\mathrm{i}}>0\right) ; \mathrm{P}_{\mathrm{i}}=$ probability

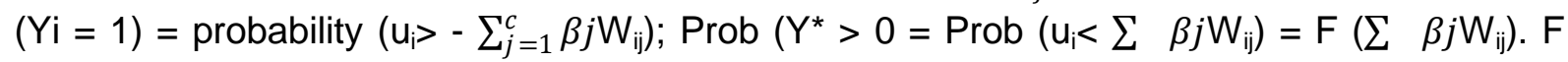
$\left(\sum \beta j \mathrm{~W}_{\mathrm{ij}}\right)$ is the cumulative density function for $\mathrm{u}_{\mathrm{i}}$ evaluated at $\sum \beta j \mathrm{~W}_{\mathrm{ij}}$. The observed probabilities $(1,0)$ are where information on the latent variable is observed through an index function. The probability that a farmer will continue with adopted technology is a function of the explanatory variables $\left(\mathrm{W}_{\mathrm{i}}\right)$, with, unobserved error term. To analyze factors considered to affect decision to continue or to abandon already adopted soil conservation technologies, four probit models were run.

\section{RESULTS AND DISCUSSION}

Below presented summary results of the probit regression analyses of factors affecting decisions to continue with the selected technologies in the study area.

Table 1 - Summary Statistics for the Results of Probit Regression Analyses

\begin{tabular}{|c|c|c|c|c|}
\hline \multirow[t]{2}{*}{ Variables } & \multicolumn{4}{|c|}{$\begin{array}{l}\text { Regression Statistics (Coefficients and t-ratios) for each Type of Soil Conservation } \\
\text { Technology }\end{array}$} \\
\hline & Stone lines & Unploughed Strips & Grass Strips & Terracing \\
\hline $\begin{array}{l}\text { Membership to Soil Conservation } \\
\text { Groups }\end{array}$ & $1.451^{* * *}(-0.99)$ & $0.276(1.61)$ & $12.87(0.09)$ & $0.236^{\star * \star}(-0.312)$ \\
\hline Capital & $0.506^{\star \star \star}(2.82)$ & $0.601(-0.12)$ & $0.158^{*}(1.71)$ & $3.71^{\star \star \star}(-2.66)$ \\
\hline $\begin{array}{l}\text { Perception of Returns to Soil } \\
\text { Conservation }\end{array}$ & $5.929^{* \star *}(2.64)$ & $2.518^{\star *}(2.47)$ & $2.412^{* * *}(2.98)$ & $0.886^{* * *}(-2.79)$ \\
\hline Access to Credit & $0.270(0.62)$ & $1.387(-0.83)$ & $0.270^{*}(1.67)$ & $0.266(1.46)$ \\
\hline Frequency of Extension Visits & $65.57(2.52)$ & $0.350(0.08)$ & $10.18(0.28)$ & $0.502(4.97)$ \\
\hline Constant & $-3.003(0.46)$ & $7.004^{* \star *}(2.08)$ & $0.379(0.02)$ & $3.396^{\star *}(1.97)$ \\
\hline $\mathrm{R}^{2}$ Value & 0.944 & 0.742 & 0.683 & 0.975 \\
\hline
\end{tabular}

${ }^{*}$ Significant at $10 \%$ level (t-critical=1.64), ${ }^{* *}$ significant at $5 \%$ level (t-critical=1.96), ${ }^{* * *}$ significant at $1 \%$ level ( $t$-critical=2.576), in brackets are $t$-ratios for estimated coefficients.

The models produced high levels of fit $\left(R^{2}=0.944\right.$ for stone lines, $R^{2}=0.742$ for unploughed strips, $R^{2}=0.683$ for grass strips and $R^{2}=0.975$ for terracing). The above results showed that all the selected variables affected decisions to continue with soil conservation. Out of 85 households that had adopted soil conservation in 1993, only 38 (44.7\%) turned out to be continuing with soil conservation in 2003.

Membership to soil conservation groups positively affected continuity of all adopted soil conservation technologies. The effect was significant at $99 \%$ confidence level for stone lines and terracing. The two technologies are highly labor intensive calling for pooling of labor through group membership. Most of the farmers who continued with soil conservation were members of soil conservation catchment committees. This contributed to their ability to maintain soil conservation measures. Catchment approach to soil conservation adopted in the area used the principle of concentrating conservation efforts and activities to within one area at a time. The approach pooled together capital needed for soil conservation. Pooling labor assisted as there was a high opportunity cost labor arising from inefficient labor market.

Capital positively affected maintenance of all analyzed soil conservation technologies. The effect was statistically significant for continued adoption of stone lines and terracing 99\% confidence level. Wealth of farmers was considered in this study as a proxy of capital and was defined as household's abundance of valuable possessions or money. Wealthy farmers had large tracts of land, larger number of salaried or able bodied family members and more assets. The positive and significant relationship between capital and continued adoption of soil conservation technologies could be explained by the fact that the two technologies were capital intensive. When land and labor markets are imperfect, farmers with large family members and land holdings were likely to use own labor to avoid low crop yield (which may translate into food insecurity) and for lack of markets to sell their surplus labor. More effort was also needed to conserve soil in large tracks of land explaining the likelihood of capital positively affecting continued maintenance of terracing and stone lines that were highly capital intensive. Family labor (a proxy of human capital) was likely to allow households to 
adopt and continue with labor-intensive practices. Use by farmers of soil conservation measures characterized by different capital intensity and/or amount of unrecoverable investments resulted in different responses by farmers to continue or abandon the adopted soil conservation technologies once external support in form of subsidies ceased. Availability of labor in the study area was affected by the high demand for labor in tea estates. The cost of hired labor was high meaning that only well-off farmers with labor constraints were more likely to afford to invest in labor intensive technologies as they could afford to hire labor.

Perception about returns to soil conservation technologies positively affected continued adoption of all analyzed soil conservation technologies. The effects were significant at $99 \%$ level for all technologies and at 95\% level for unploughed strips that was significant. The farmers who had continued with soil conservation after cessation of financial and technical support indicated this was due to increases in crop yields that were noticed after three years of soil conservation and that they did not plan to abandon the measures in future due to the perceived profits. Farmers who were found to have continued with soil conservation believed that the practices resulted in higher agricultural productivity and that investment in soil conservation improved output. When output is low, family incomes are used to smoothen household consumption needs by using the income to make purchases and not on investment in soil conservation technologies. The positive effect of perceived profits on continued adoption of all technologies is because of the fact that abandonment of soil conservation was according to most farmers costly because without soil conservation in their farms, there were many associated problems such as landslides and expensive loss of plant nutrients leading to low yields. The higher cost of abandoning than conserving delayed abandonment even if perceived profitability was low in the short run.

Access to credit positively affected decision to continue with adoption of all soil conservation technologies. The effect however was not statistically significant for all the technologies. This was explained by the fact that farmers interviewed could not access credit as credit repayment conditions excluded most the farmers selected for this study. There was a higher chance of livestock farmers accessing credit and having grass strips as soil conservation technology. Farmers sought credit for livestock improvements. The GoK investments in agriculture have been declining with the private sector expected to pick up the slack (GoK, 2002) but private investment lagged government expectations making access to credit by farmers remaining low. Restructuring in banking sector to make it internationally viable through a program of privatization and subsidy reduction (GoK, 2002) led to conditions for advancing credit exclude the vast majority of small and medium peasantry. Achievement of food self-sufficiency is impossible if so little credit is invested in and accorded to agriculture. Farmers argued that credit access did not have a strong effect on both their income and food consumption and that high interest rates were not as critical as loan program details and use restrictions in determining access to credit. Credit limited investments in ventures that entailed sunk costs.

Frequency of extension visits positively affected continued maintenance of all technologies. However, the effect was not significant. Inadequate extension services increased the probability of farmers not abandoning soil conservation measures. The low extension agent to farmer ratio could explain the effect not being significant. Among 200 farmers who provided data for the study, $68 \%$ did not receive extension advice at all. Only $15 \%$ had more than 5 contact hours in a year while the rest, $17 \%$ had less than 5 contact hours in a year. Farmers appreciated the role of extension agents of reminding them of the need to maintain soil conservation structures.

\section{CONCLUSION}

The null hypothesis that factors postulated to affect decisions to maintain adopted soil conservation technologies were not statistically significant in determining continued maintenance of the technologies was rejected. This is because the decision to maintain soil conservation technologies was affected by the variables included in the model. 
Extension visit at various levels in the study area, financial support and credit access should be improved to promote maintenance of soil conservation practices, mainly terracing since high financial and human capital is needed to establish and maintain the structures. The government of Kenya should promote and maintain soil conservation technologies as a goal towards meeting government's food security objective.

\section{REFERENCES}

1. Awinsong, M. A. (2008). The Colonial and Post-Colonial Transformation of African Chieftaincy: A Historiography. 121-128.

2. Deflem, M. (1994). Law Enforcement in British Colonial Africa: A Comparative Analysis of Imperial Policing in Nyasaland, the Gold Coast, and Kenya. Police Studies, 17(1), 45-68.

3. Domínguez, L., \& Luoma, C. (2020). Decolonising conservation policy: How colonial land and conservation ideologies persist and perpetuate indigenous injustices at the expense of the environment. Land, 9(3), 11-14. https://doi.org/10.3390/land9030065.

4. Makana, N. (2021). University Press of Florida Peasant Response to Agricultural Innovations: Land Consolidation, Agrarian Diversification and Technical Change. The Case of Bungoma District In Western Kenya, 1954-1960.

5. Mati, B. M. (2016). Overview of the: Policy, Legislative and Institutional Frameworks for Sustainable Land Management in the Public Sector in Kenya. NEPAD Planning and Coordination Agency, February, $105 . \quad$ http://www.environment.go.ke/wpcontent/uploads/2018/08/Overview-of-Policies-and-Institutional-frameworks-on-SLM-inKenya-Feb-2016.pdf.

6. Nacoulma, J. D., \& Guigma, J. B. (2015). Institutional context of soil information in Benin. July, 124.

7. Tiffen, M., Mortimore, M., \& Gichuki, F. (1994). More people, less erosion: Environmental recovery in Kenya. John Wiley \& Sons Ltd.

8. Adesina A.A and Baidu-Forsen J. (1995. Farmers Perception and Adoption of New Technology: Evidence from Analysis in Burkina Fasso and Ginuea, West Africa.

9. Adesina A.A and Zinnah M. (1993). Technology Characteristics, Farmer Perceptions and Adoption Decisions: a Tobit Model Application in Sierra Leone. Elsevier Journal of Agricultural Economics 9:297-311.

10. Adesina A.A., Mbila D., Braise, G., Nkamlau B. and Endamana D. (2002). Econometric Analysis of Determinants of Adoption of Alley Farming in the Forest Zone of southern Cameroon.

11. Anderson (1984). Depression, dustbowl, demography and drought: the colonial state and soil conservation in East Africa during the 1930s. African Affairs.

12. Anyieni Z. (1986). The Role of Permanent Presidential Commission on Soil Conservation and Afforestration in Kenya. In Proceedings of 3rd National Workshop on Soil and Water Conservation, University of Nairobi.

13. Baden-Fuller C. (1989). Exit from declining industries and the case of steel of castings. Economics Journal 99:949-961.

14. Bellon M. and Taylor J. (1993). Fork Soil Taxonomy and Partial Adoption of New Seed Varieties. Journal of Economic Development and Cultural Change 41(4): 763-786.

15. Colombo M. and Demastro M. (2001). Technology Use and Plant Closure. Journal of Policy Research.

16. Cramer J. (1991). Logit Model, an introduction for economists. Edward Armold, London.

17. Dunne T., Roberts M., and Samuelson L. (1988). Pattern of Firm Entry and Exit in U.S Manufacturing Industries. Rand Journal of Economics 19: 495-515, http://www.sciencedirect.com/science.

18. Ericksson A. (1992). The Revival of Soil Conservation in Kenya. Report No. 1. Swedish International Development Agency (SIDA) Regional Soil Conservation Unit, Nairobi.

19. Ghosh S.K. (1991). Econometrics: Theory and Applications. Prentice Hall International Inc, New Jersey.

20. Jovanovich B. (1982). Selection and Evolution of Industry. Econometrica 50:649-670. 
21. Kilewe A. and Thomas D. (1982). Land Degradation in Kenya: a Framework for Policy and Planning. Common Wealth Secretariat, Food Production and Rural Development Division, London.

22. Lieberman B. (1990). Exit from Declining Industries: Shakeout or Stakeout. Rand Journal of Economics.

23. LVEMP (1999). Lake Victoria Environmental Management Programme Newsletter.

24. Mata J., Portugal P. and Guimaraes P. (1995). The Survival of New Plants: Start-up Conditions and Post-Entry Evolution. International Journal of Industrial Organization 13: 459-481.

25. Mwenda E. (1991). Soil and Water Conservation: Field Guide Notes for Catchment Planning. Ministry of Agriculture, Livestock Development and Marketing, Nairobi.

26. Negatu W. and Parikh A. (1999). The impact of perception and other factors on agricultural technology in the Moret and Jiru Woreda (District) of Ethiopia. http://www.elsevier.nl.

27. Pindyck R. and Rubinfeld D. (1991). Econometric Models and Economic Forecasts (3rd edition). MC Graw-Hill Inc., New York (NY).

28. Pretty J., Thomson J. and Kiara J. (1995). Agricultural Regeneration in Kenya: the Catchment Approach to Soil Conservation.

29. Rahm M.R. and Huffman W.E. (1994). The Adoption of Reduced Tillage: the Role of Human Capital and other Variables. American Journal of Agricultural Economics 11: 405413.

30. SIDA (1993). From Conservation to Land Husbandry: Guidelines based on SIDA's Experience. SIDA's Natural Resource Management Division, Sweden.

31. Silberberg E. (1978). The Structure of Economics: a Mathematical Analysis. McGraw-Hill, NY.

32. Thomas D., Biamah E., Kilewe A., Lundgren L. and Mochoge B. (1986). Soil and Water Conservation in Kenya. Proceedings of the 3rd National Soil and Water Conservation Workshop, 16-19 Sept 1986. Soil \& Water Conservation Division, University of Nairobi

33. Tiffen M., Mortimore M. and Gichuru F. (1994). More people less erosion. Wiley Walker, NY.

34. Mutisya, T. W., Zejiao, L., \& Juma, N. (2010). Soil and water conservation in Kenyaoperations, achievements and challenges of the National Agriculture and Livestock Extension Programme (NALEP). Journal of American Science, 6(3), 7-15. 